\title{
Work Life of Differently Abled Public Servants in Carmen, Davao del Norte: A Case Study
}

\author{
Mike Vincent Dave B. Mullot ${ }^{1}$, Wena Lumangyao ${ }^{2}$, Bonna Mae Magbanua ${ }^{3}$, Mardy Amoroso ${ }^{4}$, Honey \\ Allones $^{5}$, Kenneth Golosinda ${ }^{6}$, Ronel G. Dagohoy ${ }^{7}$ \\ ${ }^{1-6}$ Students, Bachelor of Public Administration, Davao del Norte State College \\ ${ }^{7}$ Program Chairperson, Bachelor of Public Administration at Institute of Leadership, Entrepreneurship and Good Governance, \\ Davao del Norte State College
}

\begin{abstract}
This study assessed the work life of differently abled public servants of Carmen, Davao del Norte. This study's main objective is to unravel the experiences of local differently abled public servants. Further, assess the dimensions of their work life based on the principles of Person-in-Environment theory, including material well-being, interpersonal relations and social inclusion, personal development, and selfdetermination/actualization. This study used the qualitativedescriptive method to describe and clarify human experience as it appears in people's lives. In addition, this study was conducted in the Local Government Unit of Carmen and employed a homogenous group sampling. Participants are differently abled employees in the locality served for at least six (6) months to a year. The researchers designed an interview-guide questionnaire that elicits the dimensions mentioned above. The result has shown that seven (7) emerging themes can be extracted from the work life of differently abled public servants. The first theme is the unstable employment of the participants. Another theme derived from this study is the existence of job insecurity in the sector. The study also revealed that differently abled government employees experience work impediments and work environment plight in their work life. Lastly, the study revealed the lessons and insights that we can derive from their work lives. The result of the study will aid in creating interventions and programs that best improve and impact the work life of differently abled government employees.
\end{abstract}

Keywords - Differently Abled, Public Servants, Work Life, Philippines

\section{INTRODUCTION}

\subsection{Rationale}

I $\mathrm{n}$ the world of work, differently abled personnel tend to experience high unemployment, lower earnings than persons without disabilities, and prejudice on their productivity, which causes prevalent poverty in the sector [1]. To address this long-standing issue in the Philippine setting, Congress passed the Republic Act No. 7277, later amended into RA No. 10524, otherwise known as Magna Carta for Persons with Disabilities. The provisions of this law encourage the government and private institutions to reserve at least one percent $(1 \%)$ of the positions in their organization for the differently abled. However, the enforcement of this law bears no teeth. It merely encourages the public and private benefactors to be part of a humanitarian act [2].
Often than not, they are relegated to low-level, low-paid jobs with little social and legal security or segregated from the mainstream labor market. Study shows that available work does not ensure a living wage for those employed. Around half of working differently abled are underemployed and looking for additional sources of income. Data also shows that $45.9 \%$ of the urban PWDs and $61.9 \%$ of rural PWDs still live below the poverty line despite the passage of this law. In terms of job satisfaction, the report also stated that most employed differently abled personnel in the urban sector were not satisfied with their current work and were looking for other means to augment their finances [3]. A study's result also indicated that workers with disabilities had forty-nine percent $(49 \%)$ lower odds of high job satisfaction or more likely to be dissatisfied at work [4]. Another study also pointed out that the workplace participation of differently abled continues to be a challenge. It encompasses the hostility or indifference of some co-workers towards those with disabilities. It makes PWDs uncomfortable and affects their work efficacy [5]. Other barriers include negative attitudes, often linked to discrimination, particularly in recruitment, pay, terms and conditions of employment; lack or limited opportunities for advancement and less job security; lastly, lack of clear policy support [6].

Although these issues are present, we still appreciate initiatives that try to give this sector attention. Some localities started hiring employees that are differently abled for various positions in their municipalities. One of which is the Makati City government. In 2015, they hired twenty-five (25) PWDs wherein seven (7) became casual employees and eighteen (18) under job contracts [7]. However, the system and culture of hiring and managing differently abled in the Philippines are far from ideal and sustainable, thus affecting the job experience, growth, and retention of PWD workers [8].

There are various studies about the employability and labor force participation of this sector; however, not much data on their work life, experiences, and how they feel about their jobs. The most concerning aspect is, available data about this sector only provide a rough perspective. Not much data exist about the state of the Philippines' differently abled employees, particularly those working in the public sector [9]. 
In recognition of the instances mentioned above, the researchers find the urgency to conduct this research study to unravel the experiences of local differently abled public servants and assess what aspects of their work life is/are in a state of flight - an expression of comfort or plight the expression of predicament. The findings will contribute to the awareness of organizations such as the Department of Social Welfare and Development (DSWD) and Civil Service Commission (CSC), shedding light on how or what to improve in the system and culture of managing differently abled employees. Moreover, it adds input in the lacking pool of work life data of PWDs.

\subsection{Research Questions}

Generally, the conduct of this study will aid in investigating the experiences of differently abled at the workplace.

To be specific, the study will seek to answer to following inquiries:

1. What lived experiences are prevalent in the work life of differently abled public servants?

2. What common barriers and concerns do they face and share in their work life?

3. What lessons and insights can we extract from the work life of differently abled?

\subsection{Theoretical Lens}

The researchers wanted to unravel the lived experiences of differently abled in respect to their work life and assess what aspects of their experience are in a state of comfort or predicament. To do so, this research anchors on the following renowned authorities:

People born with certain conditions, physical or mental, or even acquired from accidents or illness, are usually regarded as disabled people. The term is not incorrect. Certain conditions can affect and even restrict normal functioning in social situations and even at work. However, it only highlights the disability of the person and eclipses individuality. Additionally, many members of this community do not appreciate or favor the said term. Thus, the most appropriate terminology that is inclusive and offers an equal platform for this sector is - differently abled [10].

The Ecological System Theory of 2000 also supports this social-illustrative inquiry [11]. It states that life and work are symptomatic in nature. It also suggests that an affective impact is produced by each and multiple characteristics that constitute work life experiences, and considers a synergy in process, person, time, and context characteristics, which results in joint function. Later on converted into the Person-inEnvironment theory, which suggests a common link among person-environment variants. In turn, it recognizes the rich and authentic relationship of individuals and groups with their physical, social, and natural environments.

The theory's principles coincide with the profound spectrum of dimensions distinguished in the conclusion of a study measuring the quality of life among adults with disabilities. It includes material well-being (financial), interpersonal relations and social inclusion (work environment), personal development (growth and advancement opportunities), and self-determination/actualization (contribution, recognition, and purpose). These areas are appropriable in the correlation, evaluation, and analysis of the work life of differently abled [12].

\subsection{Significance of the Study}

This study will provide input in the timely evaluation of the state of differently abled public servants. It will also strengthen and improve the culture of hiring and managing PWD workers. Moreover, the success of the study will be beneficial to the following:

Department Heads/Administrators: This will serve as an aid to all corporate entities such as government agencies and departments in the implementation of RA No. 10524. It will disclose relevant information concerning the work life state of differently abled. The results will also pave the way in creating better policies or guidelines in managing differently abled workers.

Differently Abled Public Servants: This study will serve as their avenue in airing out their sentiments and experiences relating to their work life in the government. It may help in improving or strengthening the work life experience of this sector.

Future Researches: The findings of this study will serve as a basis to have new knowledge in understanding the lived experiences of differently abled public servants. It will also serve as their future reference in conducting the similarly themed study, which will help further enrich the available data about this sector.

\subsection{Scope and Delimitations}

This qualitative research is primarily concerned with the accounts of differently abled public servants in the local government unit of Carmen. An in-depth interview (IDI) is going to be employed in the data collection. All of the participants are differently abled who work in the municipality. Inclusive criteria are utilized in selecting the participants of the study. All involved differently abled public servants are employed; some are under job order (contractual) while others are regular employees. The researchers did not narrow the qualification of participants based on their employment status because of the scarcity of possible participants.

When it comes to work experience, all of them must be currently working for at least six months or a year as public servants in the government to derive sufficient data. The data collection procedure started through an in-depth interview (IDI) with eight (8) participants. The participants who are the subject of the study are representatives recommended by the human resource office and DSWD personnel of the 
municipality, considering the criteria as stated above.

However, since this is a descriptive study, the findings might not generalize the experience of all differently abled workers. The researchers cannot control the diversity of the participant's physical or mental condition. Thus, the study can only suggest and derive common links present in the accounts of the local differently abled public servants, respecting their individual experiences in the process.

\subsection{Definition of Terms}

The following terms are operationally used in this study and hereby defined to give full understanding to the readers:

Differently abled Public Servant - refers to a person with a disability who works in a government setting, more specifically, as the subject of the study, who are employed in any department of the local government unit of Carmen, Davao del Norte, Philippines.

Work Life - refers to the aggregated professional experiences of differently abled employees.

\section{METHODOLOGY}

\subsection{Research Design}

The researchers utilized the qualitative descriptive method to describe and clarify human experience as it appears in people's lives [13]. Accounts or lived experiences pertain to what the subject has undergone, felt, made sense of, and accomplished. The researchers believe that studying such and gathering data for this topic will require in-depth information, which the Likert scale cannot encompass. On this note, we conducted a case study to investigate the experiences of differently abled public servants in their workplaces. This type of inquiry gives opportunities to the researchers to explore an event and situation and the best way for the informants to express their views, opinions, and subjective experiences on the study presented [14].

The data of this case study are collected from participants immersed in a government office setting. The study is geared towards this setting [15]. The researchers aspire to divulge and assess what common links present among the accounts of differently abled public servants from the Municipality of Carmen, Davao del Norte, to assess the aspects of their work life.

\subsection{Research Locale}

The study occurs in the Local Government Unit of Carmen. Being a first-class municipality in the province of Davao del Norte, it has $54.93 \%$ or more than half of its population is considered the potential workforce responsible for the economic stability of the municipality [16]. Three (3) out of five (5) PWDs are part of the working-age group (ages 15 64 years old) [17]. In the local setting of Carmen, approximately $700+$ differently abled are part of the potential workforce.

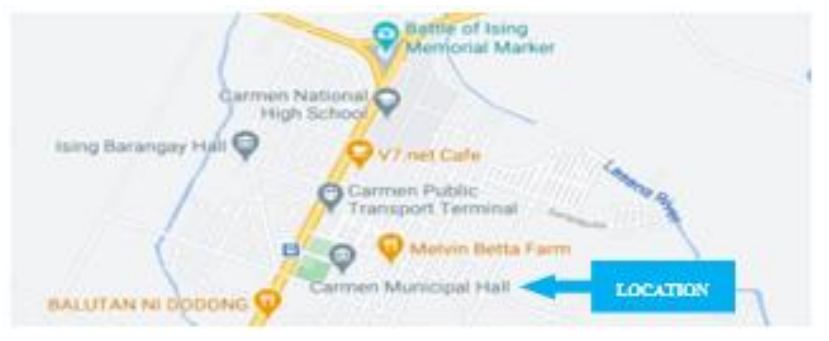

Figure 1: Carmen Municipality Hall, Davao del Norte, Philippines

\subsection{Research Participants}

The researchers decided to employ a purposive selection of data sources. The researchers did so to achieve the goal of acquiring a rich understanding of an experience. It entails choosing people or documents from which the researcher can substantially learn about the experience. With that said, it is empirical to select "information-rich cases for study in depth [18].

Employed in this study is the homogenous group sampling [19]. This type of sampling abides by the principle of information power. Information power entails isolated criteria that influence sample size. It asserts that the specificity of participant's characteristics and a richer quality of dialogue equates smaller sample size. Thus, 16 or fewer respondents is enough to derive common themes from a homogenous group, which this study qualifies. This sampling is a non-probability sample based on the characteristics of a population and the objective of the study. We used this type of sampling because of its usefulness in addressing situations, like when you need to reach an untargeted sample quickly and where sampling for proportionality is not the primary concern [20].

Consequently, the researchers only considered the available differently abled employees willing to share their experiences and not the sampling in proportion to the population of the subject of the study. That is why the researchers first reached out to the human resource office and DSWD to ensure that there are available subjects in the municipality. Afterward, we identified eight (8) possible participants as per the recommendation of the said offices stated above.

Qualitative studies vary in the kinds of experience they investigate; yet, their interest is about the experience itself and not about its distribution in a population [21]. All of the participants are differently abled who work as public servants. Therefore, the researchers included both job order (contractual) and regular differently abled employees in the local government unit of Carmen, Davao del Norte as participants of the study, without the constraints of type of job or work, in recognition of the scarcity of possible participants. When it comes to work experience, all of them must have been working for at least six months or a year as public servants in the government to share familiarity with related tasks. Researchers considered both contractual and regular employees because these two classifications of a public servants can provide substantial data of their 
experiences in public service, regardless of employment status.

\subsection{Data Gathering Procedures}

The traditional quantitative approach differs from the qualitative approach on data collection, analysis, and interpretation [22]. In the qualitative research approach, the data collection is the basis of the data source in the qualitative study questions. In addition, this entails four methods of data collection: participating in the setting, observing directly, interviewing in-depth, and analyzing documents and material culture [23]. In this qualitative inquiry, these are the steps in the data collection procedure:

\section{1) Asking permission from the Program Chairperson of ILEGG to conduct an outside campus interview, allowing the researchers to visit the location of the intended subjects of the study. \\ 2) Sending a request form to the LGU of Carmen, asking permisgion from the Human Resource Management Office to conduct an in- depth interview. Consequently, coordinating with the DSWD for further recommendation of possible participants. \\ 3) Requiring the identified participants to sign a consent forms and informing them with the details of the said study. \\ 4) Orienting the informants and participants, tackling the purpose of the study, before officially starting the in-depth interview. \\ 5) All necessary and needed materials like interview guide questionnaire, journal, and audio recorder should be prepared. \\ 6) Conducting an in-depth interview and documenting data through audio-recorder, followed by transcription and objective analygis to identify the clusters and possible emerging themes of the study. \\ Figure 2: Steps in Data Collection Procedure in Conducting the Study.}

\subsection{Data Analysis}

In this qualitative inquiry, attaining in-depth understanding will require unbiased and critical analysis. In doing so, the researchers need to interpret the data, transcribe and check, read between the lines, code, and conduct theming [24]. From the in-depth interview, the verbatim transcription of the audio recording follows.

This stage is crucial in acquiring credible data [25]. Researchers used a local dialect in the data gathering procedure. To ensure clear presentation to possible international readers and academicians, researchers decided to provide an English translation of the data gathered. [26]. After gathering sufficient input from the participants, the next stage is analyzing the data. With transcribed documents at hand, researchers proceeded to read between the lines or analysis of the transcripts. In initiating the interpretation process, the researchers kept in mind the theoretical standpoint we have taken into account, as suggested by Sutton \& Austin (2015).

Once done, the researchers will send copies of the transcripts to the participants to correct and verify the content of the transcripts. This step will ensure the authenticity of the transcripts [27]. We, later on, proceeded with the coding of the data. We identified topics, issues, similarities, and differences revealed through the participants' narratives and interpreted them once more [28]. This process enabled us to understand the world from each participant's perspective.

1) Accurate Transcription of the In-Depth-Interviews;

2) Identification of Significant Statements from the Transcription;

$\square$

3) Grouping Significant Statements into Cluster Themes;

\section{$\square$}

4) Grouping Cluster Themes According to Its Similarities;

5) Subsequently Classifying the Emerging Themes;

Figure 3: Data Analysis Procedure in Conducting the Study.

Theming came after the identification of topics, issues, similarities, and differences of participant's experiences as per dimensions of their work life. In conducting the thematic analysis, we will identify the sub-clusters, clusters, and emerging themes that can be derived [29]. We also noted the significant statements that came from the participants to back up the results and possible facets of the discussion. The arrangement of data is in a table to avoid confusion with the results of the study and for easy access and presentation of the results [30].

\subsection{Ethical Considerations}

Incorporated in this research is the study entitled 'Strategies for Ensuring Trustworthiness in Qualitative Research Projects', which aligns with positivist's standards [31]. The same criteria apply in this qualitative study. The researchers valued credibility, transferability, dependability, and confirmability in studying the accounts of differently abled public servants and their work life. We made sure that these facets of trustworthiness are intact as we conduct the study.

Credibility is the primary criterion. In establishing trustworthiness, ensuring credibility is one of the most vital factors. Internal validity is indeed critical as it assesses whether or not the study's focus is relative. Credibility is reciprocal to the relationship of the findings with reality [32]. Therefore, the results should coincide with what people experience. In this study, we made sure that the content is credible enough and coincides with the authentic lived experiences of public servants. The raw data or responses of the participants were transcribed in a verbatim fashion. Afterward, it was analyzed objectively, not adding external ideas that may question the credibility of the data and the study. 
Transferability of the study was also taken into account, as we carefully analyzed the results of the inquiry and made sure it applies to a broader population and other contexts. To simply put, transferability entails that the findings apply to diverse contexts [33].

Dependability involves participants evaluating the findings and the interpretation and recommendations of the study to make sure that they are all supported by the data received from the informants of the study [34]. Therefore, we made sure that our interpretation and recommendations are solely and objectively relative to the data we gathered through our in-depth interview. We did so to make sure that the findings are stable and reliable as readers or consumers digest its content.

Confirmability refers to the degree to which the results of an inquiry could be confirmed or corroborated by other researchers [35]. To do so, we established the data and interpretations of the findings as viable data and not derived from our imaginations. After the transcription, we sent copies of transcripts to the informants and participants for them to check, correct, and validate. The confirmability of our study is justified through an audit trail and reflexive journal. We kept a detailed record of the subject's accounts, used a journal throughout the in-depth interview for reference.

The conduct of the study involved verbal and consent forms. An endorsement letter was sought from the Human Resource Department of LGU Carmen, Davao del Norte, to conduct the Key Informants Interview. Moreover, we sent an approval letter to Hon. Virginia J. Perandos to conduct the study in the locality.

All informants and participants were kept anonymous. We safeguarded all information and valuable experiences that the participants shared throughout the study [36]. Even during the in-depth interview, we made sure that the questions we prepared are not offensive and out of line. Even in asking the questions, we took in heart to always be polite and never force the informants and participants to divulge things they do not want to. We only laid a path, through verbal sparring, possible tracks which interviewees may or may not follow in the verbal discourse. When they seemed not to understand clearly the questions we prepared, we only gave them hints of possible topics. Rest assured that their answers and the data presented in this study are according to human lived experiences.

We anchored the ethicality of our research from the Belmont Report of 1979 entitled Ethical Principles and Guidelines for the Protection of Human Subjects of Research. We adhered to empirical ethical principles like respect for persons, beneficence, and justice [37].

There are two ethical convictions included in the 'Respect for Persons'. First, we made sure that individuals are treated as autonomous agents, and second that those with diminished autonomy are entitled to protection. The requirement to recognize autonomy and the requirement to protect those with diminished autonomy are the two separate moral requirements of the standard of respect for persons.

In addressing beneficence, we made sure that their well-being is secured. Ethical treatment is done by respecting people's decisions, protecting them from harm, and securing their wellbeing. Such treatment falls under the principle of beneficence. The term "beneficence" is frequently understood to cover acts of kindness or charity that go beyond strict obligation. Two general rules are conveyed as complementary expressions of beneficent actions in this sense: (1) do not harm and (2) maximize possible benefits and minimize possible harms.

\section{RESULTS AND DISCUSSIONS}

The data gathered has been carefully analyzed and interpreted. Through the inquiry, seven (7) major themes emerged. The result and discussion of the findings on the work life of differently abled public servants in Carmen, Davao del Norte are presented below.

\subsection{Prevalent Lived Experiences}

Three (3) major themes have been identified among the lived experiences prevalent in the work life of differently abled public servants of Carmen, Davao del Norte. Shown in table 1 are the major themes and the clustered themes under them.

Table I. Major and Clustered Themes on Work Life - Lived Experiences of Differently Abled Public Servants.

\begin{tabular}{|c|c|}
\hline Major Themes & Clustered Themes \\
\hline \multirow{2}{*}{ Unstable Employment } & Rampant Job Order Status \\
\cline { 2 - 2 } & Blue Collar Jobs \\
\cline { 2 - 2 } & Low Qualifications \\
\cline { 2 - 2 } & Lack of Computer Literacy \\
\hline \multirow{2}{*}{ Job Insecurity } & Career Anxiety \\
\cline { 2 - 2 } & Perceived Poor Employability \\
\hline \multirow{2}{*}{ Volatile Job Satisfaction } & Low Salary \\
\cline { 2 - 2 } & Inconsistent Support \\
\cline { 2 - 2 } & Positive Self-Image \\
\hline
\end{tabular}

The first major theme is the unstable employment status of the participants. The majority of differently abled public servants in the locality of Carmen are only under Job Order - an openended contract. Participants also expressed the same perception of how accessible it is to qualify for a regular position or stable employment status in the government. In their years of service in the sector, they realized that it is difficult to become a regular employee. Some of the participants have been serving for more than (10) years, (7) years, and (4) years, yet still unable to acquire security of tenure.

It is notable as well that most participants are working in lowlevel, low-paid jobs. Manual labor jobs fall under the classification of blue collars. Participants revealed that the job specifications they were able to land on, since then, were 
manual labor jobs only. In addition, they attributed this experience to their low qualifications, which is due to poor educational attainment and lack of modern skills like computer literacy.

The result supports the claim of the Diversity and Equal Opportunity Centre. DEOC suggests that lack of education, nature of work, and attitudes of employers influence the employment and employability of PWDs [38]. Moreover, the results also validate the statement of Kono, who stated that the current system is inadequate to prepare and provide the sector a competitive, gainful, and secure employment [8].

Table II. Themes and Core Ideas on Work Life - Lived Experiences of Differently Abled Public Servants.

\begin{tabular}{|c|c|}
\hline Major Themes & Core Ideas \\
\hline $\begin{array}{l}\text { Unstable } \\
\text { Employment }\end{array}$ & $\begin{array}{l}\text { Participants are under an open-ended contract. } \\
\text { Lack of Security of Tenure; } \\
\text { Difficulty in acquiring regular employment status; } \\
\text { Long years of service and yet still Job Order; } \\
\text { The jobs I usually find available are manual jobs } \\
\text { only. } \\
\text { This type of work is physically demanding. } \\
\text { I need to take care of my body; If am no longer } \\
\text { physically capable, I will lose my job. } \\
\text { Unable to attain higher education or a degree; } \\
\text { I am not like college graduates who have many skills } \\
\text { and rich knowledge. } \\
\text { Considers modern skills like computer literacy as an } \\
\text { asset for better employment. }\end{array}$ \\
\hline Job Insecurity & $\begin{array}{l}\text { Gets anxious for the renewal of his/her contract; it is } \\
\text { hard not to get anxious during renewal. } \\
\text { Regular employees have security of tenure; we do not } \\
\text { have that. } \\
\text { When we apply, not only our educational attainment } \\
\text { is going to be assessed, but also our conditions. } \\
\text { I find it hard to seek a job before because of my } \\
\text { condition. } \\
\text { Before, I applied for a job but they did not accept me } \\
\text { even though I was qualified. I think they rejected my } \\
\text { application because of my condition. }\end{array}$ \\
\hline $\begin{array}{l}\text { Volatile Job } \\
\text { Satisfaction }\end{array}$ & $\begin{array}{l}\text { Low level-low paid jobs } \\
\text { I think my job satisfaction is only average. } \\
\text { Salary is not enough to support needs; } \\
\text { Resorting to loans and being in debt to survive. } \\
\text { Calling for salary increase; } \\
\text { Inconsistent support for utility workers; Providing } \\
\text { materials at work using personal money to carry out } \\
\text { tasks, } \\
\text { Approaching authorized personnel yet receiving no } \\
\text { action/solution. } \\
\text { Slow response leads to discouragement. } \\
\text { Despite of struggles, perceive himself/herself as a } \\
\text { contributing personnel in the workplace; } \\
\text { Self-image is not confined with his/her job, position, } \\
\text { or employment status; Proud serving in the } \\
\text { government sector }\end{array}$ \\
\hline
\end{tabular}

Job Insecurity is defined as the "overall concern about the continued existence of the job in the future" [39]. This experience may have a diverse definition, but in a common ground, it asserts that it is ruled by the subjective perception of a threat or uncertainty. In the context of this study, the existence of career anxiety and perceived poor employability among participants directly suggest the theme's prevalence.

Having unstable employment status, participant's anxiety towards their jobs became apparent. Participants emphasized that Job Order employees, like them, get anxious about the renewal of their contracts. Participants expressed that they feel challenged and anxious by their employment status, their condition's impact on their work, and job retention. Participants also mentioned that the ongoing pandemic amplified their anxiety. This fear is understandable given that millions of differently abled have lost their jobs due to the COVID-19 crisis [40].

The in-depth interview also revealed the participant's perception of their employability. They pointed out how more challenging it is for differently abled to apply for a job. The responses gathered from the participants also entail that they have a perception of poor employability among themselves and the sector as a whole. Perceived employability is in ties with the situational-individual factors that shape one's experience [41]. Although this perception is subjective and may not apply in every aspect, the result still mirrors the experience of many differently abled that seek employment or are currently working.

The third major theme in the work life - lived experiences of differently abled public servants of Carmen, Davao del Norte is Volatile Job Satisfaction. Participants mentioned how grateful they are for having jobs. They are delighted to participate and contribute to the labor market. However, struggles in their work life affect and influence their satisfaction. As mentioned earlier, participants revealed that their employment status falls under an open-ended contract no security of tenure. As a result, participants developed career anxiety due to the uncertainty of their employment status. In addition, employees under this contract receive low salaries and less to no benefits, unlike regular employees. This led to the volatile job satisfaction of participants. The findings reflect the result of the study entitled "Vocational Status and Perceived Well-being of Workers with Disabilities," stating that different employment statuses serve as predictors of life and job satisfaction of differently abled workers [42].

The unstable job satisfaction of participants did not affect fostering a positive self-image, which is not confined to their jobs, employment status, and negative work life experiences. As differently abled employees serving in the government, the participants embraced the identity of a public servant serving for and by the people. This sense of self or identity is attributed to how a person values work and purpose [43]. 


\subsection{Common Barriers and Concerns}

Table III. Major and Clustered Themes on Work Life - Common Barriers and Concerns of Differently Abled Public Servants

\begin{tabular}{|c|c|}
\hline Major Themes & Clustered Themes \\
\hline \multirow{2}{*}{ Work Impediments } & Struggles Due to Condition \\
\cline { 2 - 2 } & Insufficient Resources \\
\hline \multirow{2}{*}{ Work Environment Plight } & $\begin{array}{c}\text { Challenges in Expressing Sentiments and } \\
\text { Concerns }\end{array}$ \\
\cline { 2 - 2 } & Feeling Ignored \\
\hline
\end{tabular}

An impediment is anything that slows a team or an individual's progress at work. It hinders work efficiency among individuals and the organization as a whole [44]. Upon analyzing the gathered data, researchers found out that the participants are experiencing work impediments. This finding constitutes their shared concerns and common barriers in their work life.

Participants admitted that their condition impacts their work, particularly on their efficiency in carrying out tasks. This impediment is difficult to prevent due to the nature of their job, which is physically demanding. However, participants highlighted that this struggle is only natural and will not hinder them in serving and working hard at their jobs.

Work Impediments are not caused solely by the internal struggles of an employee. It can also root from external aspects, like insufficient resources in an organization. The HR Insights Blog identified six (6) causes of employee problems, including the lack of resources [45]. Participants working under low-level jobs revealed they were unable to perform their tasks efficiently due to insufficient resources. To address the impediment, participants end up providing some of the resources from their own pockets. This impediment affects both the efficiency and job satisfaction of the participants, mentioned in Table I, attributed as inconsistent support [46].

The fifth major theme that emerged is Work Environment Plight. A work environment comprises diverse elements, one of which is social behaviors and employee opinions [47]. In the context of this study, participants have a shared experience in their struggle of expressing sentiments and concern in their workplace. Facing indifference and occasionally, confronted with anger, and affected their confidence. Participants' inability to freely express themselves led them to develop a sense of fear or reluctance in expressing future concerns and sentiments. This is rooted in the systemic and cultural setup of an organization [48]. In addition, some participants expressed that they feel ignored or that their opinions are not valued.

Table IV. Themes and Core Ideas on Work Life - Common Barriers and Concerns of Differently Abled Public Servants

\begin{tabular}{|c|l|}
\hline Major Themes & Core Ideas \\
\hline Work & $\begin{array}{l}\text { Difficulty in carrying tasks due to condition; } \\
\text { There were instances that I was not able to finish } \\
\text { my work on time. }\end{array}$ \\
& $\begin{array}{l}\text { I often experience eyestrain. It is difficult for me } \\
\text { to do paperwork. That is why the paperwork }\end{array}$ \\
\hline
\end{tabular}

\begin{tabular}{|c|l|}
\hline \multirow{7}{*}{\begin{tabular}{c}
\hline Would pile up sometimes. \\
Due to mild stroke, I often experience numbness \\
in my hands and muscles. It hinders me to be \\
efficient in cleaning sometimes. \\
My articulation disorder makes it difficult for me \\
to communicate, when I answer calls. \\
As a PWD, I feel pain on my broken foot. I \\
experience cramps. At times, I even find it \\
difficult to get out of bed. I cannot work \\
properly.
\end{tabular}} \\
\hline Plight & $\begin{array}{l}\text { Difficulty in approaching authorized person; } \\
\text { Our request was blocked. } \\
\text { We are afraid of conflict. Instead, we figure } \\
\text { things by ourselves. } \\
\text { I experienced approaching but they did not help } \\
\text { me. That is why I am reluctant to approach them. } \\
\text { Hesitation in raising our concerns; } \\
\text { When someone asks for suggestions, we are not } \\
\text { confident to reply. Instead, we start pointing each } \\
\text { other. In our heads, they will still not listen to us. } \\
\text { Being unheard/Feeling Inessential }\end{array}$ \\
\hline
\end{tabular}

\subsection{Lessons and Insights}

Table V. Major and Clustered Themes on Work Life - Lessons and Insights of Differently Abled Public Servants

\begin{tabular}{|c|c|}
\hline Major Themes & Clustered Themes \\
\hline \multirow{4}{*}{$\begin{array}{c}\text { Observance of Work Values \& } \\
\text { Ethics }\end{array}$} & Punctuality \\
\cline { 2 - 2 } & Job Commitment \\
\cline { 2 - 2 } & $\begin{array}{c}\text { Perseverance } \\
\text { Reputation }\end{array}$ \\
\hline \multirow{4}{*}{ Career Aspirations } & Job Security \\
\cline { 2 - 2 } & Enhance Job Competitiveness \\
\cline { 2 - 2 } & Better Job Opportunities \\
\hline
\end{tabular}

The remaining major themes that emerged from this inquiry are Observance of Work Ethics and Values and Career Aspirations of the participants. Participants highlighted four (4) principles that they deem valuable and vital. The first one is punctuality. Punctuality signifies professionalism and helps employees stand out as reliable and trustworthy [49]. Participants value punctuality because they think that as government employees, they must set an example. Upholding this principle is well within the Memorandum Circular No. 01, series of 2017 of the Civil Service Commission (CSC) reiteration of the policy on government office hours [50].

Another practice that the participants incorporate in their work life is Job Commitment. It is the sense of responsibility that an employee has towards the mission and goals of an organization [51]. Based on the participants, their work will reflect or affect their organization. Consequently, they make sure to be thorough in their jobs. They also mentioned how dedicated and focused they are in their work. It signifies perseverance from the participants or their persistence at work despite difficulty and struggles [52]. The last work value mentioned by the participants is their aspiration to uphold their reputation and contribute to their workplace. Participants embraced the identity of a public 
servant and also its purpose. They serve by the standards and principles of the organization to which they belong. In this context, they aspire to give pride to their municipality through their work and service.

The last emerging theme of this study is the career aspirations of the participants. As indicated in Table V, participants aspire for job security, enhance their job competitiveness, and better job opportunities. As mentioned earlier, participants are only under an open-ended contract, which lacks the security of tenure. It is only natural that they would aspire to regularization of their employment status in the government sector. In addition, this will quell the career anxiety of participants towards their employment in the sector. Stable employment status would also entail better benefits and better pay for the participants. Aside from these things, participants also desire to enhance their job competitiveness. Participants suggested that PWD workers would benefit from training and livelihood programs as it bears long-term impact. For the participants, financial aids only serve as a band-aid and do not help the sector to tap their potentials. They also call for better job opportunities for PWD workers. The majority of differently abled employees are still relegated to low-level, low-paid jobs [3]. Participants think that they have more to offer and that they can actualize their potential through the utmost support of the government.

Table VI. Themes and Core Ideas on Work Life - Lessons and Insights of Differently Abled Public Servants

\begin{tabular}{|c|c|}
\hline Major Themes & Core Ideas \\
\hline $\begin{array}{c}\text { Observance of } \\
\text { Work Values \& } \\
\text { Ethics }\end{array}$ & $\begin{array}{l}\text { I always try to report early at work. I am on } \\
\text { time every day. } \\
\text { I do not want to be late at work. It is } \\
\text { embarrassing for me. } \\
\text { Being late in the government is not good. We } \\
\text { are supposed to be exemplary employees. } \\
\text { Always commit yourself to your job. } \\
\text { I am thorough with my work. } \\
\text { Serve from the heart and always do your best } \\
\text { to deliver commendable performance. } \\
\text { Despite the struggles, do not quit. } \\
\text { No matter how exhausting your job is, keep } \\
\text { doing your best. Do not be lazy. } \\
\text { Every day, I try to do my job well. } \\
\text { My great contribution to the LGU Carmen is } \\
\text { my service. We should not take our job for } \\
\text { granted. When it is time to work, you should } \\
\text { work. } \\
\text { Try your best to give pride to the } \\
\text { Municipality through your work. } \\
\text { As an employee of this Municipality, I keep } \\
\text { in mind the values and standards that I should } \\
\text { follow. } \\
\text { When you do your job well, it will reflect on } \\
\text { your workplace }\end{array}$ \\
\hline Career Aspirations & $\begin{array}{l}\text { It is not easy to become a regular employee } \\
\text { in the government but if you persevere, it } \\
\text { will happen. That is what I hope for. } \\
\text { My ambition is to become a regular } \\
\text { employee because of the benefits and better } \\
\text { job security. } \\
\text { Perhaps they could provide trainings similar } \\
\text { to NCII trainings from TESDA, so that we } \\
\text { can enrich our knowledge and improve our }\end{array}$ \\
\hline
\end{tabular}

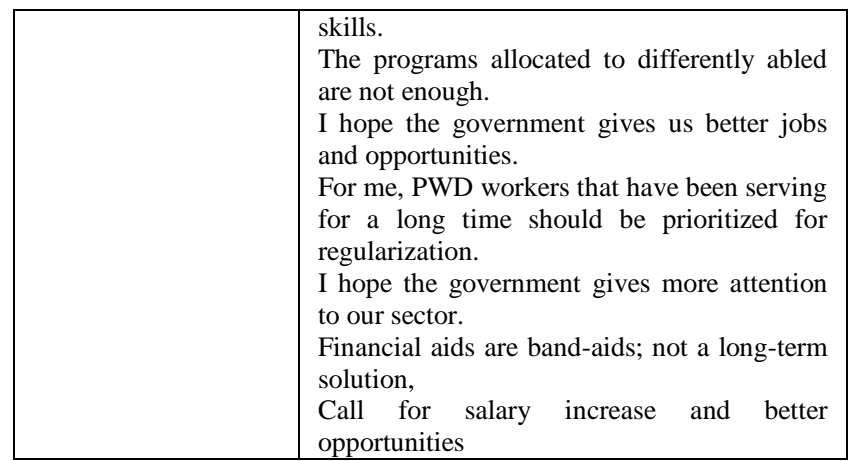

\section{SUMMARY}

This study assessed the work life of differently abled public servants of Carmen, Davao del Norte. This study's main objective is to unravel the experiences of local differently abled public servants and assess the dimensions of their work life based on the principles of Person-in-Environment theory; which includes material well-being (financial), interpersonal relations and social inclusion (work environment), personal development (growth and advancement opportunities), and self-determination/actualization (contribution, recognition, and purpose). This study used the qualitative-descriptive method to describe and clarify human experience as it appears in people's lives. In addition, this study was conducted in the Local Government Unit of Carmen and employed a homogenous group sampling, which explains why there are only eight (8) participants. Participants are differently abled employees in the locality that served for at least six (6) months to a year. The researchers designed an interview-guide questionnaire that elicits the dimensions mentioned above.

The result has shown that seven (7) emerging themes can be extracted from the work life of differently abled public servants. The first theme is the unstable employment of the participants. In this theme, core ideas like rampant job order status, blue-collar jobs, low qualifications, and lack of computer literacy constitute the experience. Another theme derived from this study is the existence of job insecurity in the sector. This theme is rooted in the career anxiety and perceived poor employability of the participants. Despite the negative experiences in their work life, participants still managed to develop a positive selfimage. However, due to low salaries and inconsistent support, participants' job satisfaction is considered volatile. The study also revealed that differently abled government employees experience work impediments and work environment issues in their work life. These themes attribute to their struggles due to condition, insufficient resources, challenges in expressing sentiments and concerns, and feeling ignored at work. Lastly, the study revealed the lessons and insights that we can derive from their work life. It includes the observance of the work values, ethics, and career aspirations of the participants. The result enfolds that differently abled public servants have a strong sense of values and work ethic. The finding will aid in creating interventions and programs that best improve and impact the work life of 
differently abled government employees.

\subsection{Implications for Practice}

Based on the findings, the following implications for practice were offered:

\section{On the policy support for differently abled public servants.}

The unstable employment status, low-level low-paid jobs, and the participant's inability to acquire security of tenure reflect the lack of or weak policy support from the government. The passage of Republic Act No. 7277, later on, amended into RA No. 10524, otherwise known as Magna Carta for Persons with Disabilities, merely encourages the public and private benefactors to consider hiring differently abled workers. However, as this law bears no teeth, it does not guarantee a spot in the labor market for differently abled [2]. Moreover, if benefactors decide to hire differently abled, they are relegated to low-level and low-paid jobs with unstable employment statuses. To address this gap, the government should review and amend the provisions of the said law to ensure competitive, gainful, and secure employment for the sector [7].

On the work impediments and work environment plight of differently abled public servants.

Work impediments are not caused solely by the internal struggles of an employee. It can also root from external aspects, like organizational shortcomings and social constraints at the workplace [45]. In the context of this study, the participant's struggle in expressing sentiments and concerns, as well as the organization's inability to support consistently their differently abled employees, led to negative work life experiences. To address this gap, the Local Government Unit of Carmen should establish an open line of communication and promote a safe space for dialogue with the participants. An employee-based civility intervention is vital to work out and dismantle the existing barriers in the organization [53].

\section{On the career aspirations of differently abled public servants.}

The career aspirations of the participants include job security, enhanced job competitiveness, and better job opportunities. These things will only come into fruition through clear policy support from the government and proactive implementation of public and private organizations [6]. Although the provisions of the Magna Carta for Persons with Disabilities include the right to be trained to develop skills for employment and the right to be trained for advancement in employment, it is difficult to gauge the level of implementation and its effectiveness [54]. Based on the latest unemployment and underemployment index in the sector, there is a need for entities like the Department of Social Welfare and Development (DSWD) and Department of Labor and Employment (DOLE) to reassess their programs and develop interventions to address this gap [3].

\subsection{Implications for Future Research}

In recognition of the limitations of this study, the following implications for future research are suggested:

Since the findings of this study are not generalized beyond the eight (8) participants, future research may be conducted investigating the experiences of differently abled government employees to confirm and reinforce the finding of the study.

In consideration of the scarcity of local researchers about the experiences and work life of differently abled workers, future researchers may replicate the study and conduct it in other municipalities in the province of Davao del Norte or even in other parts of the country where hiring and managing of differently abled personnel is present to supplement research base. Consequently, it will help address the lacking pool of work life data of PWDs. This research methodology would serve as an avenue to generalize the study findings.

Other future researches may be undertaken to distinguish whether or not the views and perceptions of the previous participants have changed over some time by interviewing them again. In addition, further research is also feasible to investigate similar issues or phenomena for this time among differently abled employees working in the private sector.

\section{ACKNOWLEDGMENT}

We express our sincere gratitude and heartfelt appreciation to the following individuals and entities whose generous support and cooperation made the writing of the study possible. To Sir Noli Blasquez, the Municipal Social Work Department Office Head of Carmen, Davao del Norte, Ma'am Cecil Tangaro, Municipal Social Worker, and Hon. Virginia Perandos, Municipal Mayor of Carmen, Davao del Norte, where the study was undertaken, for their warm accommodation during the conduct of this study. To Ma'am Mildred Ulan, for helping polish the paper. To the contributors of this research, for the unending support and sharing their knowledge, thoughts, and ideas in helping us complete our research paper. Above all, to our Almighty Father, glory and praise belong to Him for His unchanging love, new grace every morning, and for making all these things possible.

\section{REFERENCES}

[1] International Labour Organization. (2007). Facts on Disability in the World Work Retrieved from http://www.ilo.org/wcmsp5/groups/public/@dgreports/@dcomm/d ocuments/publication/wcms_087707.pdf

[2] Commission on Human Rights-Region X. (2019). Human Rights Bulletin on the Right to Equal Opportunity for Employment of Persons with Disability. Retrieved from http://chr.gov.ph/wpcontent/uploads/2020/09/CHR-X-Human-Rights-Bulletin-on-theRight-to-Equal-Opportunity-for-Employment-of-Persons-withDisability.pdf

[3] Mina, C. (2012). Employment of Persons with Disabilities (PWDs) in the Philippines: The Case of Metro Manila and Rosario, Batangas. Discussion Paper Series No. 2013-13. Philippine Institute for Development Studies. Retrieved from https://pidswebs.pids.gov.ph/ris/dps/pidsdps1313.pdf

[4] Brooks, J. D., (2018, October 24). Just a Little Respec: Differences in Job Satisfaction among Individuals With and Without 
Disabilities. Wiley Online Library. Retrieved from https://onlinelibrary.wiley.com/doi/abs/10.1111/ssqu.12543

[5] Shahin, S., Reitzel, M., Di Rezze, B., Ahmed, S., \& Anaby, D. (2020, March 31). Environmental Factors that Impact the Workplace Participation of Transition-Aged Young Adults with Brain-Based Disabilities: A Scoping Review. International Journal of Environmental Research and Public Health. Retrieved from chrome-

extension://cbnaodkpfinfiipjblikofhlhlcickei/src/pdfviewer/web/vi ewer.html?file=file:///C:/Users/user/Desktop/Environmental\%20F actors\%20fow\%20PWDs.pdf

[6] Heron, R., \& Murray, B. (2003). Assisting Disabled Persons in Finding Employment. International Labour Office. Retrieved from https://www.ilo.org/wcmsp5/groups/public/---ed_emp/--ifp_skills/documents/publication/wcms_106577.pdf

[7] Frialde, M. (2015, November 23). Makati city government hires persons with disabilities. Philstar. Retrieved from https://www.philstar.com/nation/2015/11/23/1525112/makati-citygovernment-hires-persons-disabilities

[8] Kono, A. (2015). A Glimpse of the Employment Status of Persons with Disabilities in the Philippines from a Cebuano Perspective. Disability Information Resources. Retrieved from https://www.dinf.ne.jp/doc/english/asia/resource/z00ap/vol5no1/gl impse.html\#: :text=Here\%20in\%20the\%20Philippines\%2C\%20a, access $\% 20$ to $\% 20$ quality $\% 20$ education $\% 2 \mathrm{C} \% 20$ etc.

[9] Rappler. (2016, April 3). The 2016 elections and the road to a $P W D$-inclusive $\quad P H$. Retrieved from https://amp.rappler.com/move-ph/126332-elections-pwdphilippines-platforms

[10] The Association of People with Disability. (2015, July 8). I Am Differently Abled, Not Disabled. Retrieved from https://www.apdindia.org/blog/i-am-differently-abled-not-disabled

[11] Pradhan, G. (2016). Conceptualizing Work-life Balance. The Institute for Social and Economic Change, Bangalore. Retrieved from http://www.isec.ac.in/WP\%20368\%20\%20Gayathri\%20Pradhan\%20-\%20Final.pdf

[12] Davidson, G., Irvine, R., Corman, M., Kee, F., Kelly, B., Leavey, G., \& McNamee, C. (2017). Measuring the Quality of Life of People with Disabilities and their Families: Scoping Study Final Report. Department for Communities. Retrieved from https://www.communities-ni.gov.uk/publications/measuringquality-life-disabled-people-and-theirfamilies-scoping-study-finalreport

[13] Polkinghorne, D. E. (2005). Language and Meaning: Data Collection in Qualitative Research. Journal of Counseling Psychology 2005 Vol 52, No. 2, 137 - 145, DOl: 10.1037/00220167.52.2.137. Retrieved from https://pdfs.semanticscholar.org/2fe8/4d15e6306b02da390a0f714b 7575f5043a86.pdf

[14] Zucker, D. (2009).Teaching Research Method in the Humanities and Social Sciences: How to do case study research. Retrieved fromhttps://scholarworks.umass.edu/cgi/viewcontent.cgi?article=1 $001 \&$ context=nursing_faculty_pubs; How

[15] Miller, W., Crabtree, B. (2005). Researching Practice Settings: A case study approach. In BF Crabtree and WL Miller (Eds.) Doing Qualitative Research (2nd edition, pp. 293-312). Thousand oaks', CA. Sage Publications. Retrieved from https://scholarlyworks.lvhn.org/family-medicine/49/

[16] PhilAtlas (2018). Carmen - Province of Davao del Norte. Retrieved from https://www.philatlas.com/mindanao/r11/davaodel-norte/carmen.html\#sectionDemog

[17] Philippine Statistics Authority (2013). Persons with Disability in the Philippines (Results from the 2010 Census). Retrieved from https://psa.gov.ph/content/persons-disability-philippines-results2010-census

[18] Patton, M. (1990). Qualitative Evaluation and Research Methods. Retrieved from https://legacy.oise.utoronto.ca/research/fieldcentres/ross/ctl1014/Patton1990.pdf

[19] Sim, J., Saunders, B., Waterfield, J., \& Kingstone, T. (n.d) Can sample size in qualitative research be determined a priori? Retrieved from https://core.ac.uk/download/pdf/161923816.pdf
[20] Crossman, A. (2018, September 28). What You Need to Understand About Purposive Sampling. Retrieved from https://www.thoughtco.com/purposive-sampling-3026727

[21] Jansen, H. (2010, May), The Logic of Qualitative Survey Research and its Position in the Field of Social Research Methods. Volume 11, No. 2, Art. 11. Forum Qualitative Social Research. Retrieved from research.net/index.php/fqs/article/view/1450/2946 https://www.qualitative-

[22] Creswell, J.W. (2013). Qualitative Inquiry \& Research Design: Choosing Among the Five Approaches. Retrieved from https://blogs.baruch.cuny.edu/com9640epstein/?p=543.

[23] Marshall, C., \& Rossman, G. B. (2011). Primary Data Collection Methods Designing Qualitative Research (pp. 137-177). Retrieved from https://mjcoonkitt.wordpress.com/2012/10/11/marshallrossman-2011-chapter-6/

[24] Sutton, J., \& Austin, Z. (2015). Data Collection, Analysis, and Management, Canadian Society of Hospital Pharmacists. Retrieved https://www.ncbi.nlm.nih.gov/pmc/articles/PMC4485510/

[25] MOS Legal Transcription Company. (2017, February 28). Retrieved from http://www.legaltranscriptionservice.com/blog/2017/02/4-rules-ofverbatim-transcription-and-itsimportance.html\#: :text=Verbatim\%20transcription\%20is\%20the $\% 20$ art,and\%20great\%20attention\%20to\%20detail.

[26] Goldhahn, A. (2018, June 19). The Importance of Translation Studies. University of Exeter. Retrieved from http://blogs.exeter.ac.uk/translation/blog/2018/06/19/theimportance-of-translation-

studies/\#: :text=Translation\%20is\%20necessary\%20for\%20the,e mpathetic\%20communication\%20between $\% 20$ different $\% 20$ cultur es.\&text=Translation $\% 20$ is $\% 20$ also $\% 20$ the $\% 20$ only, works $\% 20$ tha $\mathrm{t} \% 20$ expand\%20their\%20knowledge.

[27] Jaffe, I. (2011, September 01). 'Is that what I Said?' Interview Transcript Approval by Participants: An Aspect of Ethics in Qualitative Research. International Journal of Qualitative Methods. Sage Journals website. Retrieved from https://journals.sagepub.com/doi/full/10.1177/1609406911010003 04

[28] Medelyan, A. (2020). Coding Qualitative Data: How to Code Qualitative Research. Retrieved from https://getthematic.com/insights/coding-qualitativedata/\#: : text=What $\% 20$ is $\% 20$ coding $\% 20$ in $\% 20$ qualitative,recurri ng)\%20themes $\% 20$ in $\% 20$ each $\% 20$ response.

[29] Given, L. (2008). Emergent Themes: The SAGE Encyclopedia of Qualitative Research Methods. Retrieved from https://methods.sagepub.com/reference/sage-encyc-qualitativeresearch-

methods/n129.xml\#: :text=Emergent $\% 20$ themes\%20are\%20a\%20 basic,through $\% 20$ the $\% 20$ process $\% 20$ of $\% 20$ coding.\&text=Emerge nt $\% 20$ themes $\% 20$ must $\% 20$ be $\% 20$ grounded,to $\% 20$ the $\% 20$ wider $\%$ 20analytic\%20context).

[30] Vedrinelli, S., Scagnoli, N. (2013). Data Display in Qualitative Research. International Journal of Qualitative Methods. Retrieved fromhttps://journals.sagepub.com/doi/pdf/10.1177/160940691301 200117

[31] Shenton, A. (2004). Strategies for Ensuring Trustworthiness in Qualitative Research Projects. Retrieved from https://www.researchgate.net/publication/228708239_Strategies_f or_Ensuring_Trustworthiness_in_Qualitative_Research_Projects

[32] Statistics Solutions. (2017, February 21). What is credibility in qualitative research and how do we establish it? Retrieved from https://www.statisticssolutions.com/what-is-credibility-inqualitative-research-and-how-do-we-establish-it/

[33] Cohen, D. J., \& Crabtree, B. F. (2008). Evaluative Criteria for Qualitative Research in Health Care: Controversies and Recommendations. Retrieved from https://www.researchgate.net/publication/5226409_Evaluative_Cri teria_for_Qualitative_Research_in_Health_Care_Controversies_a nd_Recommendations

[34] Anney, V. (2014). Ensuring the Quality of the Findings of 
Qualitative Research: Looking at Trustworthiness Criteria (PDF File), Journal of Emerging Trends in Educational Research and Policy Studies (JETERAPS) 5(2): 272-281; Scholarship Research Institute Journals. Retrieved from https://pdfs.semanticscholar.org/1419/f7b54e6b7f1215717a5056e0 709f8946745b.pdf

[35] Statistical Solutions. (2017, June 07). What is confirmability in qualitative research and how do we establish it? Retrieved from https://www.statisticssolutions.com/what-is-confirmability-inqualitative-research-and-how-do-we-establish-it/

[36] Statistics Solutions. (2018, September 06). What is the difference between anonymity and confidentiality? Retrieved from https://www.statisticssolutions.com/what-is-the-differencebetween-anonymity-and-

confidentiality/\#: :text=Anonymity\%20means\%20that $\% 20$ there $\%$ 20 is,identify $\% 20$ participants $\% 20$ in $\% 20$ the $\% 20$ study.\&text=This $\% 20$ also\%20means\%20that\%20any,qualitative\%20research\%20th at\%20involves\%20interviews.

[37] Belmont (1979). Ethical Principles and Guidelines for the Protection of Human Subjects of Research (PDF File): The National Commission for the Protection of Human Subjects of Biomedical and Behavioral Research. Retrieved from https://globalhealthtrainingcentre.tghn.org/site_media/media/medi alibrary/2011/04/Belmont_Report_1979.pdf

[38] Diversity and Equal Opportunity Centre (2009). Base Like Report: National Centre for Promotion of Employment for Disabled People. Retrieved from http://www.dnis.org/Employment.pdf

[39] Hassard, J., Teoh, K., Cox, T. (2017, March 02). Job Insecurity. OSH WIKI Website. Retrieved from https://oshwiki.eu/wiki/Job_insecurity\#cite_note-seven-4

[40] Smith, A. (2020, August 28). A Million People with Disabilities Have Lost Jobs During the Pandemic. Retrieved from https://www.shrm.org/resourcesandtools/legal-and-

compliance/employment-law/pages/coronavirus-unemploymentpeople-with-disabilities.aspx

[41] Berntson, E. (2008). Employability Perceptions - Nature, Determinants, and Implications for Health and Well-being. Retrieved from http://www.divaportal.org/smash/get/diva2:198489/FULLTEXT01.pdf

[42] Konrad, A., Moore, M., Doherty, A., Ng, E., Breward, K. (2012, February). Vocational Status and Perceived Well-being of Workers with Disabilities. Retrieved from https://www.researchgate.net/publication/241686532_Vocational_ status_and_perceived_well-being_of_workers_with_disabilities

[43] Saunders, S., Nedelec, B. (2013, March 22). What Work Means to People with Work Disability: A Scoping Review. Retrieved from https://link.springer.com/article/10.1007\%2Fs10926-013-9436-y

[44] Meyer, S. (2016, August 12). Impediments in Scrum Project Management. Retrieved from https://study.com/academy/lesson/impediments-in-scrum-projectmanagement.html

[45] ERC (2011, June 28). 6 Causes of Employee Problems. Retrieved from https://www.yourerc.com/blog/post/6-causes-of-employeeproblems

[46] Puleo, G. (2018, July 24). Inadequate Resources, Poor Performance, and Employee Burnout: Are Managers to Blame? Retrieved https://changewithoutburnout.com/2018/07/24/inadequateresources-poor-performance-and-employee-burnout-are-managersto-blame/

[47] Glassdoor (n.d). The Work Environment: Definition, Key Features, $\begin{array}{lll}\text { and Types. } & \text { Retrieved }\end{array}$ https://www.glassdoor.com/blog/guide/work-environment/

[48] Detert, J., Edmondson, A.( 2007, May). Why Employees Are Afraid to Speak. Retrieved from https://hbr.org/2007/05/whyemployees-are-afraid-to-speak

[49] Kajdori, Y. (2015, Januray 23). Benefits of Punctuality at Work. Retrieved from https://www.linkedin.com/pulse/benefitspunctuality-work-yeukai-kajidori

[50] Civil Service Commission - Memorandum Circular No. 1, series of 2017. $\quad$ Retrieved from
http://www.csc.gov.ph/phocadownload/MC2017/mc\%20no.\%200 1\%20s.\%202017.pdf

[51] Gigli, M. (n.d.) Job Commitment: Definition \& Overview. Retrieved from https://study.com/academy/lesson/jobcommitment-definition-lesson-quiz.html

[52] Hopkin, M. (2014, October 25). What is the value in perseverance? Retrieved from https://leadonpurposeblog.com/2014/10/25/what-is-the-value-inperseverance/\#: :text=Everyone $\% 20$ who $\% 20$ takes $\% 20$ an $\% 20$ idea ,perseverance $\% 20$ is $\% 20$ they\%20take\%20time.

[53] Leiter, M. P., Laschinger, H. K. S., Day, A., \& Oore, D. G. (2011). The impact of civility interventions on employee social behavior, distress, and attitudes. Journal of Applied Psychology, 96(6), 1258-1274. Retrieved from https://psycnet.apa.org/doiLanding?doi=10.1037\%2Fa002442

[54] Reyes, D. (2015, September 30). Rights every working PWD should know about. Kalibrr Advice Website. Retrieved from https://www.kalibrr.com/advice/2015/09/rights-every-workingpwd-should-know-about 